\title{
Implementation of Educational Management Principles to Improve Teachers' Performance SMKN 6 Bone South Sulawesi
}

\author{
Ermi Sola ${ }^{1 *}$, Baharuddin $^{2}$, Muh Idris ${ }^{3}$ \\ ${ }^{1}$ Faculty of Teacher Training and Education, State Islamic University of Makassar, South Sulawesi, Indonesia \\ ${ }^{2}$ Faculty of Teacher Training and Education, State Islamic University of Makassar, South Sulawesi, Indonesia \\ ${ }^{3}$ Faculty of Teacher Training and Education, State Islamic University of Makassar, South Sulawesi, Indonesia \\ Corresponding Author*Email: ermisola18@gmail.com
}

\begin{abstract}
The research aims at studying the implementation of management principles toward the improvement of performance. This study is descriptive qualitative research with phenomenology and a symbolic interaction approach. The data collected from the principal, teachers, and staff through observation, questionnaires, and documentation. The analysis was by data reduction, data display, and conclusion. The validity of the data was by triangulation. The result was showed that SMKN 6 Bone South Sulawesi has implemented the principles of educational management well by practicing Division of Work, Authority Responsibility, Problem Solving, Participation, and Professionalism. Based on the result of the research, it suggested that the principal of SMKN 6 Bone South Sulawesi develops the teachers' performance with educational management principles as the basis in managing the school to achieve the goal and increase the quality of teaching and learning --education.
\end{abstract}

Keywords: implementation, educational management principles, effectiveness

\section{INTRODUCTION}

\subsection{Background}

Educators, in general, are to educate, which is seeking development around the potential participants of learners, the potential cognitive, affective and potential psychomotor. A teacher must educate and teach only based on love for a fellow human being without looking at the status of the social economy, religion, nationality, and so on. School as a formal educational institution is one of the central points of education and learning for students. The quality of education for each school is not the same. It is happening because of the strategy of the management and the power of school managers. It is from two aspects, namely the quality of its components and the quality of its managers.
Educational management is a series of activities in the form of a cooperative business management process for a group of people to achieve the predetermined educational goal by utilizing existing resources and using management functions to achieve goals effectively and efficiently. [1] School effectiveness is a measure of the level of achievement of school goals. The higher the level of achievement of school goals, the more effective school management will be. The achievement of the school objective depends on school capacity.[2] Criteria for the effectiveness of the organization include schools between others, 1) Production/results, 2) efficiency, 3) Satisfaction, 4) Adaptation, and 5) Continuity of life.[3] The effectiveness of the teacher's performance relates to the planned learning, implementation, and achievement of objectives of the learning set. It relates to the competence of which is owned by the teacher, especially competence pedagogic educator. 
Performance is the result of the work of an individual or a group of people in an organization according to their respective authorities and responsibilities in an effort to legally achieve the organization's goals, namely not to violate law, morals or ethics. Or the work results both in quantity and quality achieved by an employee in carrying out his duties according to the responsibilities assigned to him.[4] A teacher must be professional in carrying out his tasks as an educator in achieving learning goals. He is said a professional when his inherent dedication is high, as well as continuous improvement, and his commitment to the quality of the process and the results of his work. The teacher's performance can be said effective if the roles and responsibilities he replied implemented professionally. Plan a program of learning that is structured, implemented as a groove achievement of the purpose of learning itself. The principles of management include 1) humanity, 2) democracy, 3) the right man on the right place, 4) equal pay for equal work, 5) the similarity direction, 6) unity of command, 7) efficiency and effectiveness, 8) the productivity of task, 9) discipline and 10) authority and responsibility. By utilizing the ninth principles, the teacher's performance as educators can reap the optimal results.

Based on the background, it was found varieties of problems on the implementation of the principles of management to improve the teacher's performance. Some of them are: 1) teachers do not pay attention to the condition of participant/learners, 2) teachers are not professional, 3) some teachers are not discipline, and 4) division of labor is not oriented to the competence and background of teachers. Those problems brought about fewer effective teachers.

\subsection{Problem Formulation}

Based on the background behind at the top, the problem formulated as follows:

1. How to describe the management principles of SMKN 6 Bone South Sulawesi?

2. How is the description of the effectiveness of the teacher's performance at SMKN 6 Bone, South Sulawesi?

3. How is the description of the implementation of management principles in increasing the effectiveness of teacher's performance at SMKN 6 Bone, South Sulawesi?

\subsection{Research Focus}

The study focused on two variables, namely the principles of educational management. The indicators are work division, authority and responsibility, participation, and professionalism. Then, the effectiveness of teacher's performance about the competence of the pedagogic.

\section{THEORETICAL REVIEW}

\subsection{Definition of Educational Management}

Management is a science that studies the steps to achieve goals effectively and efficiently through systematic planning, organizing, implementing, and monitoring.[3] Managing personnel education aims to harness education effectively and efficiently to achieve the objective, but still in a fun condition.

\subsection{Principles of Educational Management}

\subsubsection{Division of work}

Work division is carried out systematically. It is because it involves the process of achieving the goals of the organization and the interests of employees. Employees need a type of duty following their competency, abilities, and interests. Worker's mismatch with the duties can disrupt and hinder the process.[5] Good work division can create efficient use of power and more practical at energy, time, and cost. There are some factors in work division are:

a) Helping coordination.

b) Streamlining supervision.

c) Specialization benefits.

d) Save costs.

e) Emphasizes the relationship between people.

\subsubsection{Authority and Responsibility}

The balance between authority and responsibility is crucial because the imbalance between the two can lead to various problems. The followings are the authority owned by a leader.

a) Delegating tasks/jobs to subordinates.

b) Arrange and divide the job description or picture/description of duties.

c) Assess staff performance.

d) Provide rewards and punishments to staff/subordinates.

e) Make decisions. 
f) Formulating and establishing policies.[3]

Dealing with the authority, the principal of the school as a leader also has responsibilities on his shoulders:

a) Being responsible for the decisions.

b) Develop and maintain the organization.

c) Motivating staff.

d) Capacity to handle the pressure.

e) To coordinate duty.[3]

\subsubsection{Participation}

Community participation can be implemented in the construction of the school. Participation involves the contribution of the planning, supervision, and control of the program of the school.[6] Participation given by the stakeholders of the program should be in terms of improving the quality of education. The program was adjusted with the teacher's competencies. Thus, the program is planned realistic and implemented by teachers.

\subsubsection{Professionalism}

Professionalism is the ability of the member of a profession to improve the ability and continuously develop strategies used in performing the tasks or works according to his/her profession.[7] Many professionals demonstrate the quality of their duty by the desired standards and receive positive recognition from the public or client. The results are achieved as proof to the public for the task they do. The quality of a professional teacher can be viewed from five attitudes, namely:

1. The desire to always display work results under ideal standards.

2. Always improve his professional image.

3. Having a desire to develop the quality of knowledge and skills.

4. Always pursue quality and aspirations in the profession.

5. Having pride in their profession .[3]

\subsection{Teacher Performance Effectiveness}

Effectiveness demonstrates the ability of the organization to achieve the goals which have been set as appropriate. The achievement corresponds to the target determined by the size and standard that reflects the organization. It has noticed the effectiveness of its operations. Schools are not only required to pursue the goal itself but also what purpose could be achieved effectively and efficiently.[8]
Performance is a function of competence, attitudes, and actions. Competence describes the characteristics of the knowledge, skills, behaviors, the experience to do a job, or role-specific as effective. Rate implementation of job performance is the system used to assess and determine whether someone has been carrying out his duty as a whole. Employees were expected to demonstrate their performance routinely and regularly to maintain the effectiveness of it. At the bottom this is some procedure assessment of performance on them:

1. Setting performance standards.

2. Assessment of actual performance with standards.

3. Giving feedback to employees to motivate them to eliminate a decrease in performance or continued to improve their performance.[9]

\section{RESEARCH METHODOLOGY}

This research is a qualitative descriptive study with taking location in SMKN 6 Bone. The approach used in obtaining this research is the phenomenological approach and symbolic interactions. Data research sourced person, place, and paper through observation, in-depth interviews, and documentation.

The main research instrument is the researcher himself and developed using observation, interview, and documentation guidelines. The mechanical process and analysis of data were through Data Reduction, Data Display, and Conclusion Drawing / Verification. Test validity or the validity of the data carried out with the extension of observation, increased diligence in research, discussions with colleagues, triangulation (data/source of information, analysis of negative cases, and member check.[10]

\section{RESEARCH RESULT}

SMK 6 Bone South Sulawesi has implemented several principles of management to improve the effectiveness of the performance of teachers in schools, in whom:

1. Division of Work (a division of labor) that do SMKN 6 Bone South Sulawesi based background behind education, placement of teachers by the competencies that are owned. However, some teachers in the competence of certain more much while on the competence of other shortcomings, so that the formations are filled by other teachers for the sake of the smooth process of learning though not following the background behind the education that he had. 
2. Authority Responsibility (the authority and responsibility in charge) are shown with their programs of activities that vary are implemented to attempt to achieve the vision, mission and objectives, and programs of education and teaching. In terms of making policies, the principal tries to minimize any pressure on teachers in implementing learning programs. The Head of the school actively controls the performance of teachers and strives to improve the performance of teachers to do supervision or assessment tools of learning.

3. Participation; in decision-making and policy, the head of the school gives space for teachers to absorb the aspirations of them. Likewise, the meeting routine that held the head of the school is intended to evaluate the results of the work/performance of teachers and developmental progress of study participants learners.

4. Professionalism; the efforts of teachers to display work results/performance by implementing procedures and school institutional policies by both teachers who teach in their fields and teachers who teach not in their fields.

\section{CONCLUSIONS AND SUGGESTION}

1. Basically, the principles management already implemented in SMK Negeri 6 Bone South Sulawesi well. Implementation of these is based on indicators such as division of work, authority responsibility, participation, professionalism.

2. The effectiveness of teacher performance at SMK Negeri 6 Bone can be seen from the discipline of the teacher in making learning plans complete with learning tools, starting from planning, implementing, and evaluating the learning process to measure the absorption of students.

3. The school principal recommended continuing and developing the teachers to make the principles of management as a basis in managing the school in efforts to achieve objectives that have been set and improve the quality of education and teaching.

\section{REFERENCES}

[1] M. Kustiawan, D. Safitri, and R. Lestari, Manajemen Pendidikan. Yogyakarta: Deepublish, 2017.

[2] C. Triatna, Pengembangan Manajemen Sekolah, Cet. I. Bandung: PT. Remaja Rosdakarya, 2015.

[3] C. Chaerunnisa, Manajemen Pendidikan dalam Multi Perspektif. Jakarta: PT. Raja Grafindo Persada, 2016.

[4] A. P. Mangkunegara, Manajemen Sumber Daya Perusahaan. Bandung: PT. Remaja Rosdakarya, 2013.

[5] D. Laksmi, Manajemen Perkantoran Modern, Cet I. Raja Grafindo Persada, 2015.

[6] Engkoswara and A. Komariah, Administrasi Pendidikan, Cet. II. Bandung: Alfabeta, 2012.

[7] Saidah, Pengantar Pendidikan: Telaah Pendidikan Secara Global dan Nasional. Depok: Raja Grafindo Persada, 2016.

[8] Amirullah, Pengantar Manajemen. Jakarta: Mitra Wacana Media, 2015.

[9] Sedarmayanti, Manajemen Sumber Daya Manusia, Cet. IV. Bandung: PT. Refika Aditama, 2010.

[10] Sugiyono, Metode Penelitian Pendidikan: Pendekatan Kuantitatif, Kualitatif, dan $R \& G$, Cet. XXII. Bandung: Alfabeta, 2015. 